University of South Carolina

Scholar Commons

4-30-1999

\title{
Coupling Between Bacterioplankton Species Composition, Population Dynamics, and Organic Matter Degradation
}

\author{
Jarone Pinhassi \\ Umeå University \\ Farooq Azam \\ University of California - San Diego \\ Johanna Hemphälä \\ Kalmar University \\ Richard A. Long \\ University of South Carolina - Columbia, longra@mailbox.sc.edu \\ Josefina Martinez \\ University of California - San Diego
}

See next page for additional authors

Follow this and additional works at: https://scholarcommons.sc.edu/biol_facpub

Part of the Biology Commons

\section{Publication Info}

Aquatic Microbial Ecology, ed. Tom Fenchel, Volume 17, Issue 1, 1999, pages 13-26.

(C) Aquatic Microbial Ecology 1999, Inter-Research.

This Article is brought to you by the Biological Sciences, Department of at Scholar Commons. It has been accepted for inclusion in Faculty Publications by an authorized administrator of Scholar Commons. For more information, please contact digres@mailbox.sc.edu. 


\section{Author(s)}

Jarone Pinhassi, Farooq Azam, Johanna Hemphälä, Richard A. Long, Josefina Martinez, Ulla Li Zweifel, and Åke Hagström 


\title{
Coupling between bacterioplankton species composition, population dynamics, and organic matter degradation
}

\author{
Jarone Pinhassi ${ }^{1}$, Farooq Azam ${ }^{2}$, Johanna Hemphälä ${ }^{3}$, Richard A. Long ${ }^{2}$, \\ Josefina Martinez ${ }^{2}$, Ulla Li Zweifel ${ }^{3}$, Åke Hagström ${ }^{3, *}$ \\ ${ }^{1}$ Department of Microbiology, Umeâ University, S-90187 Umeå, Sweden \\ ${ }^{2}$ Marine Biology Research Division, Scripps Institution of Oceanography, University of California San Diego, La Jolla, \\ California 92093-0202, USA \\ ${ }^{3}$ Marine Science, Kalmar University, Box 905, S-39129 Kalmar, Sweden
}

\begin{abstract}
To study the effect of substrate addition on short term bacterial population dynamics and species composition in seawater, mesocosms were maintained with water collected off Scripps Pier (La Jolla, California, USA). Protein enrichment (BSA) triggered a dynamic response from the microbial food web, whereas enrichment with starch had no effect. In the protein enriched mesocosm the number of both nucleoid-containing cells and metabolically active cells increased by $3.0 \times 10^{5}$ cells $\mathrm{ml}^{-1}$ from Day 1 to Day 4. In the same time period the density of a set of 31 phylogenetically different bacteria ( $\alpha$ - and $\gamma$-Proteobacteria as well as Flexibacter-Cytophaga-Bacteroides) increased by $3.5 \times 10^{5}$ cells $\mathrm{ml}^{-1}$. The abundance of these isolated bacteria accounted for up to $89 \%$ of the nucleoid-containing cells, and up to $22 \%$ of the total counts. Increased enzyme activities, most notably protease, were found concomitant with a change in bacterial species composition over $3 \mathrm{~d}$. This short term succession was possible due to rapid net growth rates of single bacterial species in the mesocosm $\left(0.48\right.$ to $\left.1.6 \mathrm{~d}^{-1}\right)$, which was up to 5 times higher than the community turnover calculated from bacterial production and total counts. These results should provide support for studies of actual bacterial population dynamics on the species level and its role in the degradation of organic matter in the aquatic environment.
\end{abstract}

KEY WORDS: Bacterioplankton · Species · Growth $\cdot$ Hybridization

\section{INTRODUCTION}

Population ecology is an emerging theme in marine microbiology where both spatial and temporal variation can be observed among specific populations of bacterioplankton (Lee \& Fuhrman 1991, Rehnstam et al. 1993, Ferris et al. 1996, Giovannoni et al. 1996, Pinhassi et al. 1997). A logical next step is therefore to try to capture the dynamics of bacterial populations in relation to substrate variations. To do this a major hurdle will be to determine the dominant species in the observed bacterial community. With an ongoing

\footnotetext{
- Addressee for correspondence.

E-mail: ake.hagstrom@ng.hik.se
}

debate on the degree of culturability of marine bacteria, the protocol used should ideally be culture independent (Suzuki et al. 1997). In natural systems colony forming units (CFU) provide an inadequate description of the relative abundance of bacteria, although solid media may still be useful for isolation of significant members of the bacterial community. Rehnstam et al. (1993) compared the abundance of specific bacteria by 16 S rRNA probing of the bacterial community DNA and by colony hybridization with the same probes. Their results showed no relationship between strength of the hybridization signal towards community DNA and the CFU. The explanation of this discrepancy has been inferred to be low plating efficiency due to virus infection (Rehnstam et al. 1993). Thus, although pre- 
sent in low numbers on the agar plates, the same species may still occupy a significant fraction of the bacterial community, Other authors have also convincingly demonstrated that cultivable bacteria may well be numerically important components of the bacterial community (Fuhrman et al. 1994, Moran et al. 1995, González \& Moran 1997, Kalmbach et al. 1997, Pinhassi et al. 1997. Tuomi et al. 1997). Hence, a reasonable compromise could be to use a culture independent assay technique based on information from cultured bacteria.

Using whole-genome DNA probes towards community DNA, Pinhassi et al. (1997) demonstrated seasonal dynamics in the abundance of different colony-forming marine bacteria. These bacteria showed a considerable diversity, with isolates distributed among the $\alpha-$, $\beta$-, $\gamma$-Proteobacteria and the Flexibacter-CytophagaBacteroides phylum (Pinhassi et al. 1997). This would indicate that a multitude of growth strategies could be found among pelagic bacteria, for instance in the different kinds of ectoenzymes expressed. Martinez et al. (1996) investigated and found that different pelagic marine bacteria have different ectohydrolytic enzyme profiles, rendering them different capabilities to degrade various substrates. This result can easily be linked to earlier studies demonstrating seasonal dynamics in enzyme activity as well as different enzyme activity along trophic gradients (Chróst 1989, Rath et al. 1993). Thus, it is tempting to conclude along with Martinez et al. (1996) that different enzyme activities in the water column are most likely the result of proliferation of different species.

The capacity of marine bacteria to rapidly adjust their growth rate to new growth conditions as well as the capacity for high growth rates of specific bacteria indicate the possibility of rapid changes in the composition of the bacterial community (Chin-Leo \& Kirchman 1990, Zweifel et al. 1993, 1995). However, few studies have addressed this question directly. In an attempt to study the short term changes in the bacterial community composition during the degradation of the diatom Skeletonema costatum and the copepod Tigriopus japonicus, Fukami et al. (1985) monitored the number of CFU, and classified the identity of the bacteria growing on the plates (Fukami et al. 1985). They showed that within days a succession took place, with different bacterial groups becoming dominant in the 2 treatments. In their experiment the CFU made up a significant fraction of the bacterial community, which makes their results an interesting exception providing an indication of the potential for rapid population dynamics within the bacterial community. However, for a more relevant assessment of succession under in situ conditions culture independent techniques must be employed.
In this study we demonstrate short term population dynamics in bacteria and follow the changes in enzymatic activity in response to substrate addition. We accomplished this by the use of fluorogenic substrate analogues and a culture independent protocol where the abundance of different species of bacteria in the bacterial community could be monitored.

\section{MATERIALS AND METHODS}

In situ sampling. Surface seawater ( $0.5 \mathrm{~m}$ depth) was collected off the Scripps Pier $\left(32^{\circ} 53^{\prime} \mathrm{N}, 117^{\circ} 15^{\prime} \mathrm{W}\right)$ using an acid rinsed $20 \mathrm{l}$ polyethylene bucket. The seawater was brought to the laboratory and samples were processed within $2 \mathrm{~h}$. During the experimental period the seawater temperature decreased from 17.5 to $15.5^{\circ} \mathrm{C}$.

Mesocosm experiments. Two sets of nesocosm experiments were performed at Scripps in December 1995. The aim of the control experiment was to determine the reproducibility among 3 mesocosms and how well the mesocosms maintained the in situ bacterial activity. This experiment lasted from 4 to 8 December. The addition experiment aimed at surveying the response of specific bacterial populations to substrate addition of complex organic nutrients lasted from 12 to 18 December. Surface seawater for the mesocosms was collected by lowering a carefully rinsed polyethylene carboy $(60$ l) into the water. The water was then prefiltered through a $130 \mu \mathrm{m}$ net to eliminate large zooplankton and partitioned between three 2001 polyethylene vessels (Nalgene). The mesocosms were each filled with $\sim 150 \mathrm{l}$. The mesocosms were transferred within $30 \mathrm{~min}$ to a $15^{\circ} \mathrm{C}$ temperature-controlled room with an artificial light source (12 h light and $12 \mathrm{~h}$ dark) corresponding to $2.7 \%$ of the in situ light $\left(5.26 \mu \mathrm{E} \mathrm{cm} \mathrm{cm}^{-2}\right.$ in situ, $0.14 \mu \mathrm{E} \mathrm{cm} \mathrm{cm}^{-2}$ in the mesocosms). The mesocosms were aerated with a slow stream of $0.2 \mu \mathrm{m}$ filtered air to provide mixing. In the addition experiment nutrients were added to give an addition of $30 \mu \mathrm{M} \mathrm{C}$ as starch or $9.16 \mu \mathrm{M} \mathrm{N}$ as Bovine Serum Albumine (Sigma). Sampling was done daily during the experiments, between 10:00 and 11:00 h. No sampling was done on Day 6 of the addition experiment (17 December).

Bacterial and flagellate enumeration. Samples for enumeration of total counts of bacteria (TC) and heterotrophic nanoflagellates (HNF) were preserved with $0.2 \mu \mathrm{m}$ filtered formaldehyde, and were counted within $48 \mathrm{~h}$. Total counts of bacteria were determined by epifluorescence microscopy using 4',6-diamidino2-phenylindole (DAPI) to stain the cells (Porter \& Feig 1980). Cells were stained with a final concentration of $2 \mu \mathrm{g}$ DAPI $\mathrm{ml}^{-1}$ sample for $10 \mathrm{~min}$ and thereafter fil- 
tered onto black $0.2 \mu \mathrm{m}$ filters at a pressure of 100 to $200 \mathrm{~mm} \mathrm{Hg}$. Numbers of nucleoid-containing bacteria (NUCC) were quantified according to Zweifel \& Hagström (1995), using a modified protocol to accommodate samples with higher salinity (Zweifel \& Hagström 1995). Sodium azide was added to a final concentration of $0.1 \mathrm{M}$ to the samples and the samples were preserved over night. The samples were thereafter diluted 5 times with sterile particle free $M Q$ water for $1 \mathrm{~h}$ to allow equilibration of the cells, then stained with DAPI (final concentration $2 \mu \mathrm{g}$ DAPI ml ${ }^{-1}$ sample ) for $2 \mathrm{~h}$, and finally filtered onto black $0.2 \mu \mathrm{m}$ polycarbonate filters at $100 \mathrm{~mm} \mathrm{Hg}$. Nonspecific binding of DAPI to the cell walls was removed by filtering $5 \mathrm{ml} 2$ propanol through the filters. The number of 5-cyano2,3-ditolyl tetrazolium chloride (CTC) reducing bacteria was determined by using a final concentration of 2 mM CTC (Rodriguez et al. 1992), and incubating the sample at in situ temperature $\left(15^{\circ} \mathrm{C}\right)$ for $2 \mathrm{~h}$ (longer incubation time resulted in no further increase in CTC positive cells). Samples were filtered onto $0.2 \mu \mathrm{m}$ black polycarbonate filters and counted within $2 \mathrm{~h}$. The number of cyanobacteria was determined by autofluorescence. The number of fields (typically 20) was varied to maintain the standard error of the microscopic enumeration at $<5 \%$. Flagellate enumeration was done by filtering $20 \mathrm{ml}$ of preserved seawater samples onto $0.6 \mu \mathrm{m}$ black polycarbonate filters at $100 \mathrm{~mm} \mathrm{Hg}$ and staining with a $0.003 \%$ acridine orange solution. The number of colony forming units (CFU) was determined by plating $50 \mu \mathrm{l}$ of undiluted, and $100 \mu \mathrm{l}$ of $10 \times, 100 \times$, and $1000 \times$ diluted seawater samples in triplicates on ZoBell agar plates (ZoBell 1946). Plates were incubated at in situ temperature $\left(15^{\circ} \mathrm{C}\right)$ until no more colonies appeared ( 10 to $15 \mathrm{~d}$ ).

Density of specific bacteria. The density of specific bacteria was determined by whole genome DNA hybridization towards community DNA according to the species density protocol of Pinhassi et al. (1997), where sampling procedures and sample preparation are extensively described. The procedure in brief was as follows. Community DNA samples were prepared by filtering $15 \mathrm{ml}$ sample water onto hybridization membranes, lysing the cells with sodium hydroxide, and linking the DNA to the hybridization membrane by UV-exposure. From the agar plates used for determination of CFU in the 2 experiments we selected 96 different isolates on the basis of colony morphology. Bacterial isolates were collected from all the sampling dates. To distinguish different bacterial species and avoid duplicates we determined the 16S rRNA gene sequences on 59 of the isolates (see below). The remaining isolates were either duplicates or failed to grow during subsequent cultivation. Thirty-one of the sequenced bacteria were found to belong to different species and from these strains standard curves with known numbers of cells were prepared using the same protocol as for the samples. Whole genome DNA probes were then prepared by labelling the genomic DNA prepared from each of the different bacteria with a nick translation kit (Promega) and [ $\left.\alpha-{ }^{32} \mathrm{P}\right] \mathrm{dATP}$ (Amersham). Each probe was then hybridized to triplicate community DNA samples and to the specific standard curve under stringent hybridization conditions $\left(69^{\circ} \mathrm{C}\right)$ and washing conditions (washed twice, $30 \mathrm{~min}$ each time, in $2 \times \mathrm{SSC}-0.5 \%$ sodium dodecyl sulfate at the hybridization temperature and twice, 5 min each time, in $0.1 \times \mathrm{SSC}$ at room temperature). The hybridization signal was detected and quantified using a PhosphorImager (Molecular Dynamics). The density of the specific bacteria was obtained by relating the hybridization signal of the samples to the hybridization signal of the standard with a known number of cells.

Cross hybridization between the different bacteria was assessed by hybridization of extracted DNA. The DNA from the different isolates was blotted onto hybridization membranes according to the manufacturer (Hybond-N, Amersham), using a slot blot apparatus (GIBCO BRL). Membranes, each containing slots of DNA from the 31 different bacteria, were included in the quantitative hybridizations described above.

PCR-amplification, purification of PCR product and sequencing. $16 \mathrm{~S}$ rRNA gene sequences of 59 bacterial isolates from the mesocosms were amplified by means of PCR using Taq polymerase (Boehringer-Mannheim) from DNA preparations of cultured isolates. Bacterial 16S rDNA primers, 27f:biotinylated (AGAGTTTGATCATGGCTCAG) and 1492r (TACGGYTACCTTGTTACGACTT), were used for amplification (Giovannoni 1991). The reaction volumes were $50 \mu \mathrm{l}$, containing $1 \mu \mathrm{g}$ template, $10 \mathrm{mM}$ total dNTP, standard $10 \times$ Taq buffer, a total of $15 \mathrm{ng}$ of each primer, and $1 \mathrm{U}$ of Taq polymerase. The PCR amplification conditions were as follows: 1 round of denaturation at $95^{\circ} \mathrm{C}(2 \mathrm{~min})$, annealing at $50^{\circ} \mathrm{C}(30 \mathrm{~s})$ and elongation at $72^{\circ} \mathrm{C}(45 \mathrm{~s})$ and then $29 \mathrm{cycles}$ of $95^{\circ} \mathrm{C}(30 \mathrm{~s}), 50^{\circ} \mathrm{C}(30 \mathrm{~s})$ and $72^{\circ} \mathrm{C}$ (45 s) using a DNA thermal cycler 480 (Perkin Elmer). The biotinylated strand was purified using streptavidine coated magnetic beads (Dynabeads M280-Streptavidin, Dynal AS., Norway). $25 \mu$ of Dynabeads were washed once in TES (TE + 0.1 M NaCl), resuspended in $50 \mu \mathrm{l}$ TES and incubated for $30 \mathrm{~min}$ with the $50 \mu \mathrm{l}$ PCR reaction at room temperature. The beads were kept in suspension by gently tapping the tubes every $2 \mathrm{~min}$. The biotinylated strand was separated by denaturing for 5 min with $100 \mu \mathrm{l} 0.15 \mathrm{M} \mathrm{NaOH}$ and washing once with TES and once with water. The Dynabeads with the purified biotinylated strand were resuspended in $11 \mu \mathrm{l}$ water. $16 \mathrm{~S}$ rDNA nucleotide sequences were determined from the purified single stranded 
PCR product by automated sequencing, using $A B I$ PRISM Dye Terminator Cycle Sequencing (Perkin Elmer) with primer 518r (CGTATTACCGCGGCTGCT) (Lane et al. 1985). The accession numbers to the $16 \mathrm{~S}$ rRNA gene sequences of the isolates are presented in Table 1.

Bacterial production. Bacterial production was measured using both the $\left[{ }^{3} \mathrm{H}\right]$-thymidine incorporation method (Fuhrman \& Azam 1982) and the $\left[{ }^{3} \mathrm{H}\right]$-leucine incorporation method (Kirchman et al. 1985), as modified by Smith \& Azam (1992). Samples for tritiated thymidine incorporation (TTI) were incubated with 10 $n M\left[{ }^{3} \mathrm{H}\right]$-thymidine (final concentration). A conversion factor of $2 \times 10^{18}$ cells $\mathrm{mol}^{-1}$ incorporated thymidine was applied to the data. Samples for tritiated leucine incorporation (TLI) were incubated with $10 \mathrm{nM}\left[{ }^{3} \mathrm{H}\right]$ leucine (final concentration) and the uptake of leucine was converted to bacterial carbon production using the conversion factors of Simon \& Azam (1989). For both methods triplicate samples of $1.7 \mathrm{ml}$ each were incubated for 1.5 to $2.0 \mathrm{~h}$, at in situ temperature. The standard deviation for incorporation of the radioactive labels was $\leq 10 \%$ of the mean. Bacterial specific growth rates were calculated by normalizing the TTI to the number of bacteria obtained through different methods of enumeration (TC, NUCC, CTC, and the total density of the 31 different bacteria). Net specific growth rates $(\mu)$ were also calculated from the accumulation of cells by using the growth equation $\mu=$ $\ln \left(\mathrm{N}_{2} / \mathrm{N}_{1}\right) / t$

Ectoenzyme activity in mesocosms and seawater. Ectoenzyme activities were measured using fluorogenic substrates (Hoppe 1983, Hoppe et al. 1988) derived from 7 -amino-4-methyl-coumarin (AMC) and

Table 1. Bacterial species isolated from the mesocosms and quantified by the species density protocol. The closest relative in the EMBL sequence data bank with its accession number is indicated. Expt when dominant indicates whether a given species became dominant and in which treatment. Addition refers to protein enrichment. Control refers to the first experiment (not to the the control of the second experiment)

\begin{tabular}{|c|c|c|c|c|}
\hline Isolate & Accession number & Closest matching organism in EMBL & $\begin{array}{l}\text { Similarity } \\
(\%)\end{array}$ & $\begin{array}{l}\text { Expt when dominant } \\
\left.\text { (net growth rate, } \mathrm{d}^{-1}\right)^{\mathrm{a}}\end{array}$ \\
\hline $\mathrm{SCB} 41$ & U64018 & Flavobacterium uliginosum; M62799 & 85.4 & \\
\hline SCB36 & U64013 & Flexibacter maritimus; M64629 & 85.7 & Addition $(1.65)$ \\
\hline SCB38 & U64015 & Capnocytophaga canimorus; L14637 & 87.5 & Addition $(0.98)$ \\
\hline SCB37 & U64014 & Antarcticum vesiculatum $\mathrm{M}_{\mathrm{i}} \mathrm{61002}$ & 87.7 & Addition $(1.60)$ \\
\hline $\mathrm{SCB} 40$ & U64017 & Flavobacterium gondwanense; M92278 & 88.2 & \\
\hline SCB46 & $\mathrm{U} 64023$ & Flexibacter manitimus; M64629 & 91.0 & \\
\hline SCB45 & $\mathrm{U} 64022$ & Marinobacter hydrocarbonoclasticus; X67022 & 93.1 & Controli Addition (0.54) \\
\hline SCB50 & U64027 & Marinomonas vaga; $\times 67025$ & 93.1 & \\
\hline $\mathrm{SCB} 23$ & $\mathrm{U} 64000$ & Chromohalobacter marismortui, X87219 & 93.2 & \\
\hline SCB22 & U63999 & Marinobacter hydrocarbonoclasticus; $\mathrm{X} 67022$ & 94.1 & \\
\hline SCB28 & U64005 & Roseobacter algicola $\times 78313$ & 94.4 & Control \\
\hline SCB48 & U64025 & Roseobacter algicola $\times$ X78313 & 94.4 & Addition $(0.71)$ \\
\hline SCB27 & $\mathrm{U} 64004$ & Xanthomonas maltophila; M59158 & 94.8 & \\
\hline SCB29 & U64006 & Vibrio nereis; $\times 74716$ & 95.1 & \\
\hline SCB44 & U64021 & Antarcticum vesiculatum; M61002 & 96.2 & Addition (3.06) \\
\hline SCB26 & U64003 & Erythrobacter longus; M59062 & 96.3 & \\
\hline $\mathrm{SCB} 34$ & U64011 & Roseobacter algicold; $\times 78313$ & 96.3 & Control \\
\hline SCB54 & AF052599 & Alcanovorax borkumii, Y12579 & 96.8 & Control \\
\hline SCB21 & U63998 & Sphingomonas macrogoltabidus; D 12723 & 96.8 & \\
\hline SCB30 & U64007 & Vibrio splendidus $X \times 7424$ & 96.9 & \\
\hline SCB25 & $\mathrm{U} 64002$ & Rhizobium loti; U50165 & 97.0 & \\
\hline SCB33 & U64010 & Alteromonas macleodi; $\mathrm{X} 82145$ & 97.1 & Control \\
\hline SCB33 & U64016 & Vibrio tubiaghi, Y74725 & 97.1 & \\
\hline $\mathrm{SCB} 42$ & U64019 & Antarctic gas vacuolate bacterium; U14583 & 97.2 & Control; Addition (0.95) \\
\hline SCB35 & U64012 & Pseudoalteromonas nigrifaciens; $\times 821.46$ & 97.7 & \\
\hline SCB31 & U64008 & Roseobacter algicola; X78313 & 97.9 & Addition $(0.48)$ \\
\hline SCB56 & A.F052601 & Alteromonas macleodii; $\times 82145$ & 98.3 & \\
\hline SCB32 & U94009 & Suffitobacter pontiacus; Y13155 & 98.4 & Addition (1.36) \\
\hline SCB 43 & $\mathrm{U} 64020$ & Pseudoalteromonas carrageenovora; $\mathrm{X} 82136$ & 99.6 & Control; Addition (1.16) \\
\hline SCB24 & U64001 & Pseudomonas stutzeri; U25280 & 99.8 & \\
\hline SCB55 & A.F052600 & Alteromonas macleodii; $\times 82145$ & 99.8 & \\
\hline
\end{tabular}


4-methyl-umbelliferone (MUF). Protease activity was assayed as the hydrolysis rate of leucine-AMC, $\alpha$-DGlucosidase and $\beta$-D-glucosidase activities were assayed as the hydrolysis rate of MUF- $\alpha$-D-glucoside and MUF- $\beta$-D-glucoside, respectively. MUF-oleate was used to assay lipase activity. Alkaline phosphatase was assayed using MUF-phosphate. Chitinase activity was assayed using MUF- $N$-acetyl- $\beta$-Dglucosamine. Enzyme activities measured by means of fluorogenic substrates were expressed in terms of the rate of MUF or AMC production. The substrates were added to the samples $(5 \mathrm{ml})$ at a final concentration of $20 \mu \mathrm{M}$. Samples were run in triplicates with killed controls.

\section{RESULTS}

\section{Control experiment: assessment of reproducibility}

To assess the experimental system 3 mesocosms were surveyed by daily sampling for $5 \mathrm{~d}$. Samples were collected for bacterial species composition, bacterial production, and ectoenzyme activity. Parallel samples were taken off Scripps Pier (origin of mesocosm seawater), where bacterial numbers and production rates were monitored to allow a comparison of mesocosm data to in situ values. The comparison of measured bacterial parameters in the replicate mesocosms demonstrated that the bacterial community developed similarly, and the comparison to in situ values showed that the microbial food web in the experimental system could be maintained in a manner that resembled the natural situation during $5 \mathrm{~d}$.

\section{Bacterial numbers and production}

Bacterial numbers were stable in the 3 mesocosms during the $5 \mathrm{~d}$ of sampling. The total counts, number of nucleoid-containing cells, and the number of tetrazolium chloride reducing bacteria averaged $1.5 \times 10^{6}$ $4.1 \times 10^{5}$ cells ml ${ }^{-1}$ and $8.1 \times 10^{4}$ cells $\mathrm{ml}^{-1}$, respectively, These numbers were similar to those found at the pier (Fig. 1). In the mesocosms the fraction of cells containing a nucleoid was on average $27 \%$ of the TC and the CTC positive cells comprised $20 \%$ of the NUCC $(5 \%$ of the TC). Similar fractions of NUCC and CTC to TC were found in the in situ samples (Fig. 1). The CFU in the 3 mesocosms remained $<3.3 \times 10^{4} \mathrm{CFU} \mathrm{ml}{ }^{-1}$ throughout the sampling period. The cyanobacteria numbers in the mesocosms and at the pier were similar the first $2 \mathrm{~d}\left(6.0 \times 10^{4}\right.$ cells $\left.\mathrm{ml}^{-1}\right)$, but thereafter the mesocosm values declined 6 -fold while the numbers at the pier were stable.

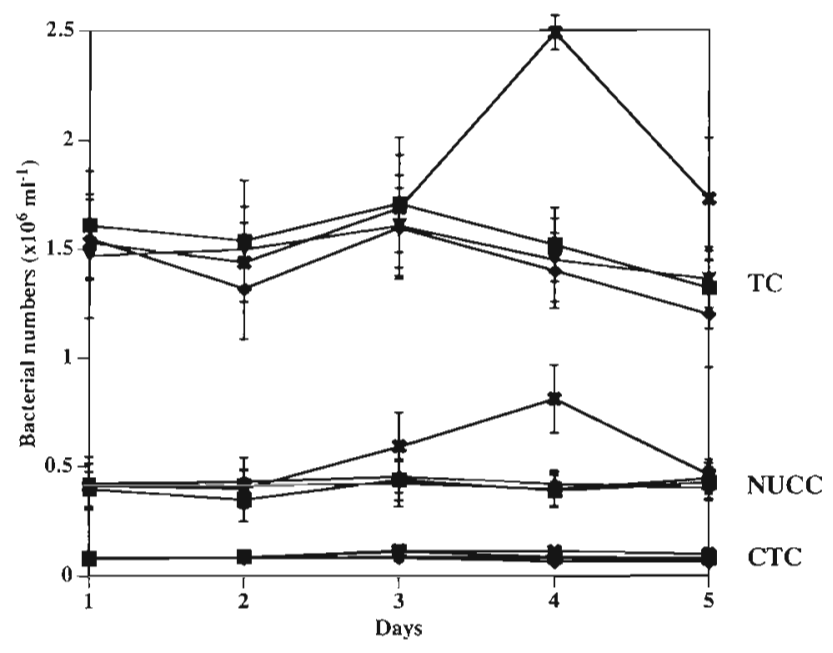

Fig. 1. Bacterial numbers in the 3 mesocosms and at the Scripps Pier during the control experiment. Bacterial numbers were determined as total counts (TC), nucleoid containing cells (NUCC), and tetrazolium chloride reducing bacteria (CTC) in mesocosm 1 (四), $2(\bullet), 3(\mathbf{v})$, and at Scripps Pier $(\mathbf{x})$. Error bars indicate standard deviations $(\mathrm{n}=30$ )

The bacterial production in the 3 mesocosms averaged $1.5 \times 10^{8}$ cells $\mathrm{l}^{-1} \mathrm{~d}^{-1}$, measured as TTI. The pattern of the TLI during the experiment was similar to the TTI, with an average carbon production of $3.0 \mu \mathrm{g} \mathrm{C} \mathrm{l}^{-1}$ $\mathrm{d}^{-1}$ (Fig. 2). There was some initial variation in bacterial production in the 3 mesocosms, but the rates converged during the experiment. The in situ bacterial production was similar to the bacterial production in the mesocosms, but increased slowly throughout the experimental period.

The community turnover rate obtained when relating bacterial production (measured as TTI) to the total count of bacteria averaged $0.09 \mathrm{~d}^{-1}$ in the 3 mesocosms during the control experiment. Based on the number of NUCC and CTC the specific turnover was 0.3 and $1.5 \mathrm{~d}^{-1}$, respectively. These values were close to the turnover rates calculated at the pier which were 0.08 , 0.25 , and $1.30 \mathrm{~d}^{-1}$ when determined from TC, NUCC and CTC, respectively. The maximum turnover rates in the mesocosms are shown in Table 2.

\section{Density of specific bacteria}

During the control and addition experiment the abundance of 31 different isolated bacterial species was determined according to the species density protocol (Table 1). Since this assay is based on wholegenome DNA hybridization towards community DNA collected in the mesocosms, the possible cross hybridization between isolates was also determined and was generally found to be low $(<1 \%)$. The low 

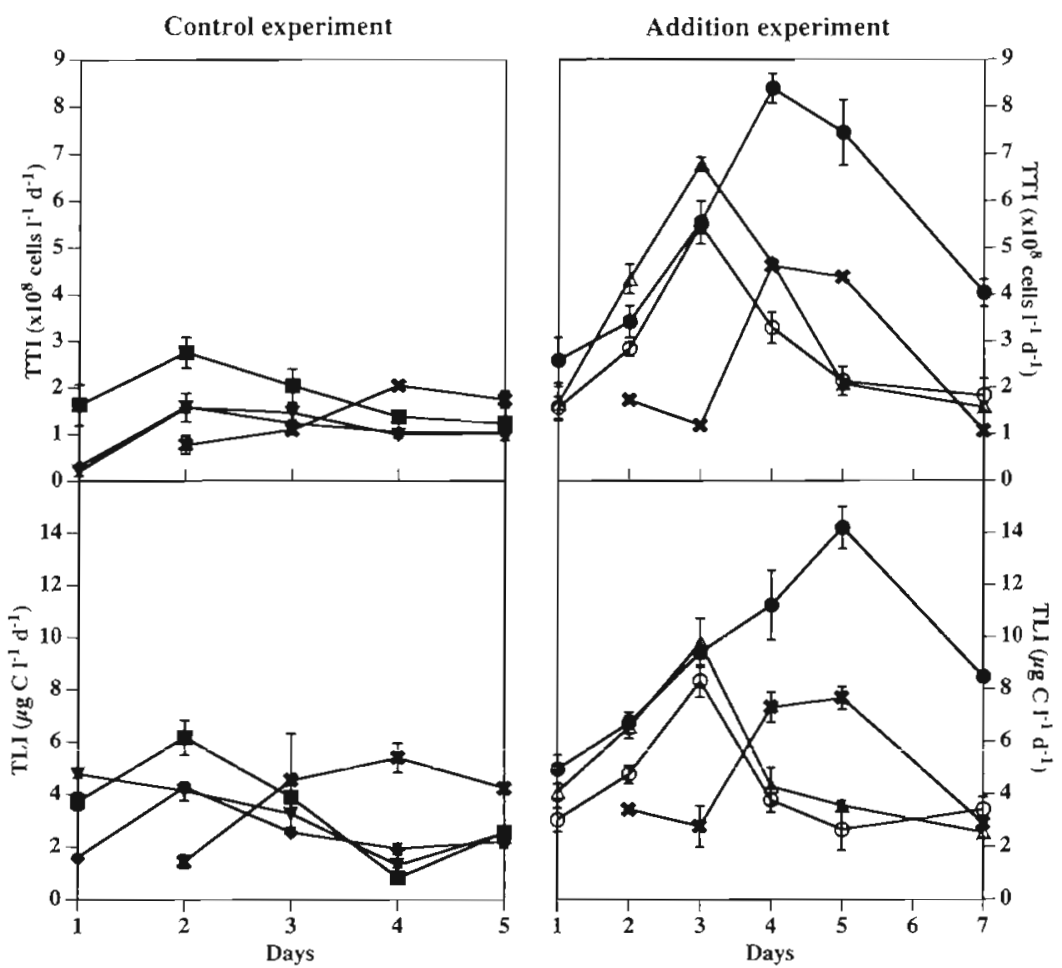

Fig. 2. Bacterial production during the 2 experiments, as determined by tritiated thymidine incorporation (TTI) and tritiated leucine incorporation (TLI). The data for mesocosm $1(\boldsymbol{\nabla}), 2(\bullet), 3(\boldsymbol{v})$ in the control experiment are shown compared to the data from Scripps Pier (x) sampled in parallel. Changes in bacterial production in the different mesocosms during the addition experiment: protein meso$\operatorname{cosm}(\bullet)$, starch mesocosm $(0)$, control $(\Delta)$, and at the Scripps Pier $(\mathbf{x})$. Error bars indicate standard deviations $(n=4)$ cross hybridization was in accordance with the phylogenetic analysis done by comparison of sequence similarity values between any pair of isolates and phylogenetic trees (data not shown); for a further discussion of the specificity of the probes see Pinhassi et al. (1997). Three different isolates that were most similar to Alteromonas macleodii (SCB33, -55, -56) showed elevated cross hybridization levels. Between SCB33 and -56, SCB33 and -55, and SCB55 and -56 the cross hybridization was $2.8,3.5$, and $16 \%$, respectively. The $16 \mathrm{~S}$ rRNA gene sequence similarities among these isolate pairs were $95.9,96.5$, and $98.3 \%$ for SCB33 and $-56, \mathrm{SCB} 33$ and -55 , and SCB55 and -56, respectively.

In the control experiment the total density of the different bacteria averaged $3.0 \times 10^{5}$ cells $\mathrm{ml}^{-1}$ during the first $3 \mathrm{~d}$ and then declined to $1.5 \times 10^{5}$ cells $\mathrm{ml}^{-1}$ on Day 4 and 5 . The 7 most abundant bacterial species each occurred at similar densitjes in the different mesocosms, but decreased somewhat in abundance during the experiment (Fig. 3). The $\gamma$-proteobacterium SCB54 was the single most dominant species and peaked at 1.26

Table 2. Turnover rates in the control experiment (mean \pm SD of the 3 replicate mesocosms at highest specific growth rates) and in the addition experiment (highest specific growth rates in the protein mesocosm), determined from the numerical net increase as well as rates calculated from bacterial production (TTI) and different fractions of the bacterial community (TC, NUCC, CTC, and the total density of the 31 different bacteria). Also presented are the values of numerical net increase from which net rates of increase for various parameters in the protein mesocosm have been calculated

\begin{tabular}{|c|c|c|c|c|}
\hline & \multirow{3}{*}{$\begin{array}{l}\text { Numerical net increase } \\
\text { from Day } 1 \text { to } 4 \\
\text { (protein mesocosm) }\end{array}$} & \multirow{3}{*}{$\begin{array}{l}\text { Determined from } \\
\text { numerical net increase } \\
\text { Addition expt } \\
\text { Day } 1 \text { to } 4 \text { in } \\
\text { protein mesocosm }\end{array}$} & \multirow{2}{*}{\multicolumn{2}{|c|}{$\begin{array}{l}\text { Turnover }\left(\mathrm{d}^{-1}\right) \\
\text { Determined from } \\
\text { TTI and cell numbers }\end{array}$}} \\
\hline & & & & \\
\hline & & & $\begin{array}{l}\text { Control } \\
\text { expt }\end{array}$ & $\begin{array}{c}\text { Addition } \\
\text { expt }\end{array}$ \\
\hline TC & $1.47 \times 10^{6} \mathrm{colls} \mathrm{ml^{-1 }}$ & 0.27 & $0.13 \pm 0.04$ & 0.30 \\
\hline NUCC & $3.2 \times 10^{5}$ cells ml $^{-1}$ & 0.17 & $0.50 \pm 0.23$ & 1.18 \\
\hline CTC & $2.8 \times 10^{5}$ cells $\mathrm{ml}^{-1}$ & 0.54 & $2.13 \pm 0.60$ & 4.83 \\
\hline All isolates ${ }^{b}$ & $3.5 \times 10^{5}$ cells $\mathrm{mi}^{-1}$ & 0.51 & $0.68 \pm 0.23$ & 1.82 \\
\hline 10 dominant isolates $^{c}$ & $1.9 \times 10^{5}$ cells ml $\mathrm{m}^{-1}$ a & $0.93^{d}$ & & \\
\hline $\mathrm{SCB} 37$ & $5.8 \times 10^{4}$ cells ml $\mathrm{ml}^{-1} \mathrm{a}$ & $1.59^{\mathrm{d}}$ & & \\
\hline CFU & $1.8 \times 10^{5}$ cells ml ${ }^{-1}$ & 1.6 & & \\
\hline Protease & $3370 \mathrm{pmol} \mathrm{AMC} \mathrm{ml} \mathrm{An}^{-1} \mathrm{~h}^{-1}$ & 0.94 & & \\
\hline \multicolumn{5}{|c|}{${ }^{a}$ Data from Day 2 to 4 only } \\
\hline \multicolumn{5}{|c|}{${ }^{\mathrm{b}}$ The abundance of 31 different bacteria was determined by the species density protocol } \\
\hline \multicolumn{5}{|c|}{ 'These isolates were dominant during the addition experiment in the protein mesocosm, see Fig. 3} \\
\hline
\end{tabular}


$\pm 0.09 \times 10^{5}$ cells $\mathrm{ml}^{-1}$ (mean $\pm \mathrm{SD}$ ) on Day 3 of the experiment. The second most abundant species was a Roseobacter sp. (SCB28), which averaged $0.46 \pm 0.05$ $\times 10^{5}$ cells $\mathrm{ml}^{-1}$ (mean $\pm \mathrm{SD}$ ) during the first $3 \mathrm{~d}$ but showed a slight decline during the last $2 \mathrm{~d}$. The other 5 dominant species, e.g. SCB33, $-34,-42,-43,-45$ were present in densities ranging from 1.0 to $2.2 \times 10^{4}$ cells $\mathrm{ml}^{-1}$ during the first $3 \mathrm{~d}$. These species taken together with the less abundant ones $\left(<1.7 \times 10^{4}\right.$ cells $\mathrm{ml}^{-1}$ ) represented 20 and $10 \%$ of the TC at the beginning and end of the experiment, respectively. However, since the number of cells containing a nucleoid was found to be only $27 \%$ of the TC, the total density
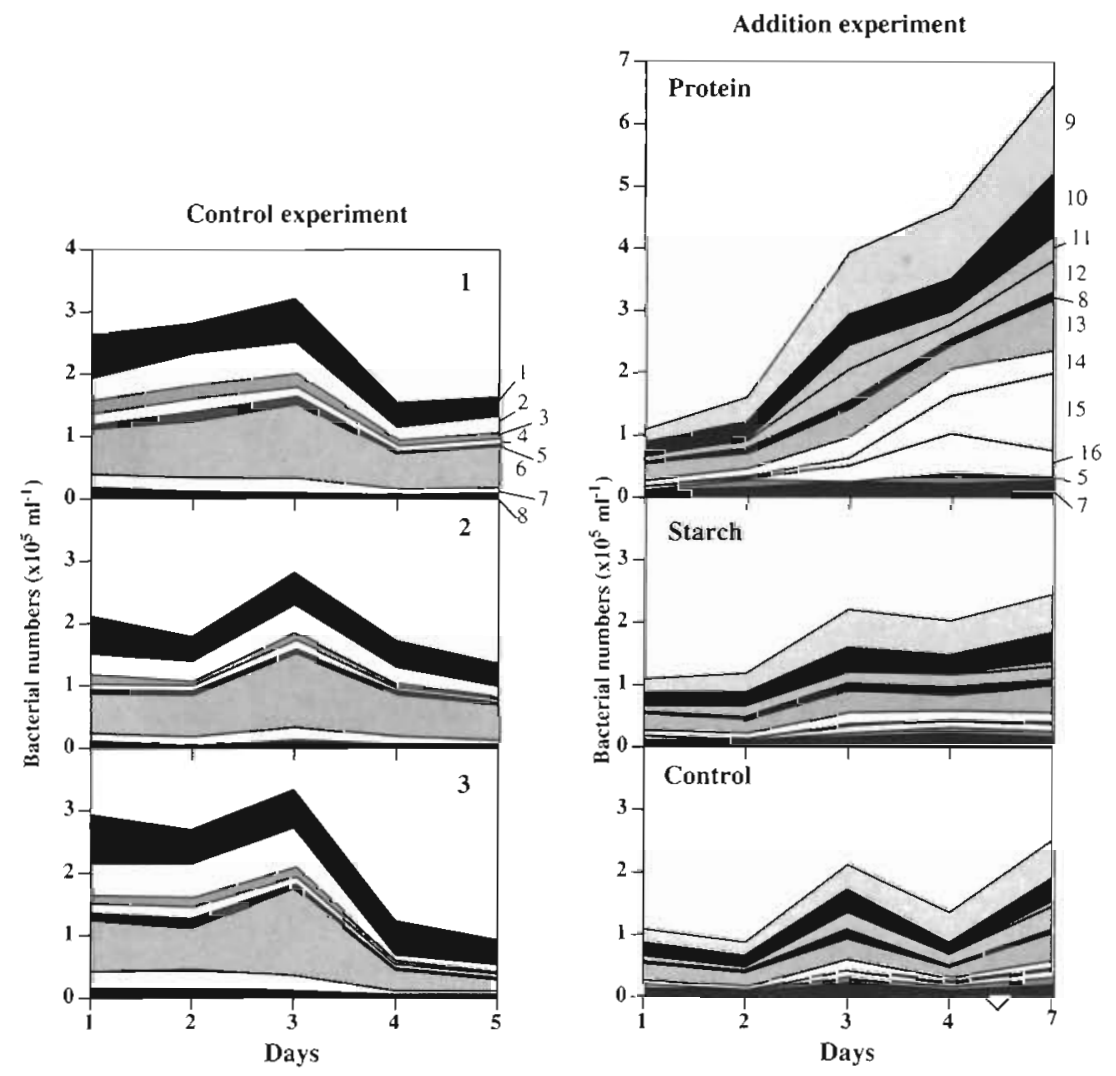

Fig. 3. Changes in the density of the different species of bacteria in the mesocosms during the control experiment and during the addition experiment, determined by the species density protocol. (1) Total of the less abundant bacteria (24 species, none exceeding $1.7 \times 10^{4}$ cells $\left.\mathrm{ml}^{-1}\right)$; (2) SCB28 $(94.4 \%$ similar to Roseobacter algicola, X78313); (3) SCB33 (Alteromonas macleodii); (4) SCB34 (96.3\% similar to $R$. algicola, X78313, and $94.5 \%$ similar to SCB28); (5) SCB43 (99.6\% similar to Alterornonas carrageenovora, X82136); (6) SCB54 (96.8\% simllar to Alcanovorax borkumi); (7) SCB45 (89.6\% similar to Flectobacillus sp. U14584); (8) SCB42 (97.2\% similar to Antarctic gas vacuolate bacterium, U14583); (9) all less dominant bacteria; (10) SCB31 (97.9\% similar to $R$. algicola, X78313); (11) SCB44 (96.2\% similar to Antarcticum vesiculatum, M61002) (12) SCB32 (98.4\% similar to Sulfitobacter pontiacus, Y13155); (13) SCB48 $(94.4 \%$ similar to $R$. algicola, X78313); (14) SCB38 (87.5\% similar to Capnocytophaga canimorus, L14637); (15) SCB37 (87.7\% similar to $A$. vesiculatum, M61002); (16) SCB36 (85.7\% similar to Flexibacter maritimus, M64629). Note the interrupted scaling of the $x$-axis in the panel for the addition experiment

\section{Ectoenzyme activity}

Ectoenzyme activity in the 3 mesocosms was measured by the hydrolysis of fluorogenic substrates for 6 enzymes (protease, lipase, $\alpha$ - and $\beta$-glucosidase, alkaline phosphatase, and chitinase). Activity levels were mesocosms and only minor changes in the enzyme activity were recorded with time (Fig. 4).

At the end of the control experiment, a pilot experiment was performed where protein (BSA, $9 \mu \mathrm{MN}$, final concentration) and starch $(30 \mu \mathrm{M} \mathrm{C}$, final concentration) were added to mesocosm 1 and 2, respectively. The mesocosms were sampled again for ectoenzyme activity 3 d after the addition, and BSA triggered a significant increase in the activity of all measured ectoenzymes; protease increased 16-fold, alkaline phosphatase increased 15 -fold and lipase increased 6-fold. Addition of starch caused less dramatic effects, with a 4 -fold increase in $\alpha$-glucosidase and a 6 -fold increase in $\beta$-glucosidase (data not shown)

\section{Addition experiment: substrate induced community response}

For the second experiment the 3 mesocosms were cleaned, rinsed, and refilled with seawater. One mesocosm was amended with protein (BSA, $9 \mu \mathrm{MN}$, final concentration). This protein addition corresponded to an approximate doubling of the DON concentration measured in the area (Williams 1986). A second mesocosm was amended with starch $(30 \mu \mathrm{M} \mathrm{C}$, final concentration) resulting in a carbon addition roughly equivalent to that in the protein. Finally, a third mesocosm served as a control. Since in the initial control experiment it was shown that replicate mesocosms behaved similarly, 1 unamended meso- 


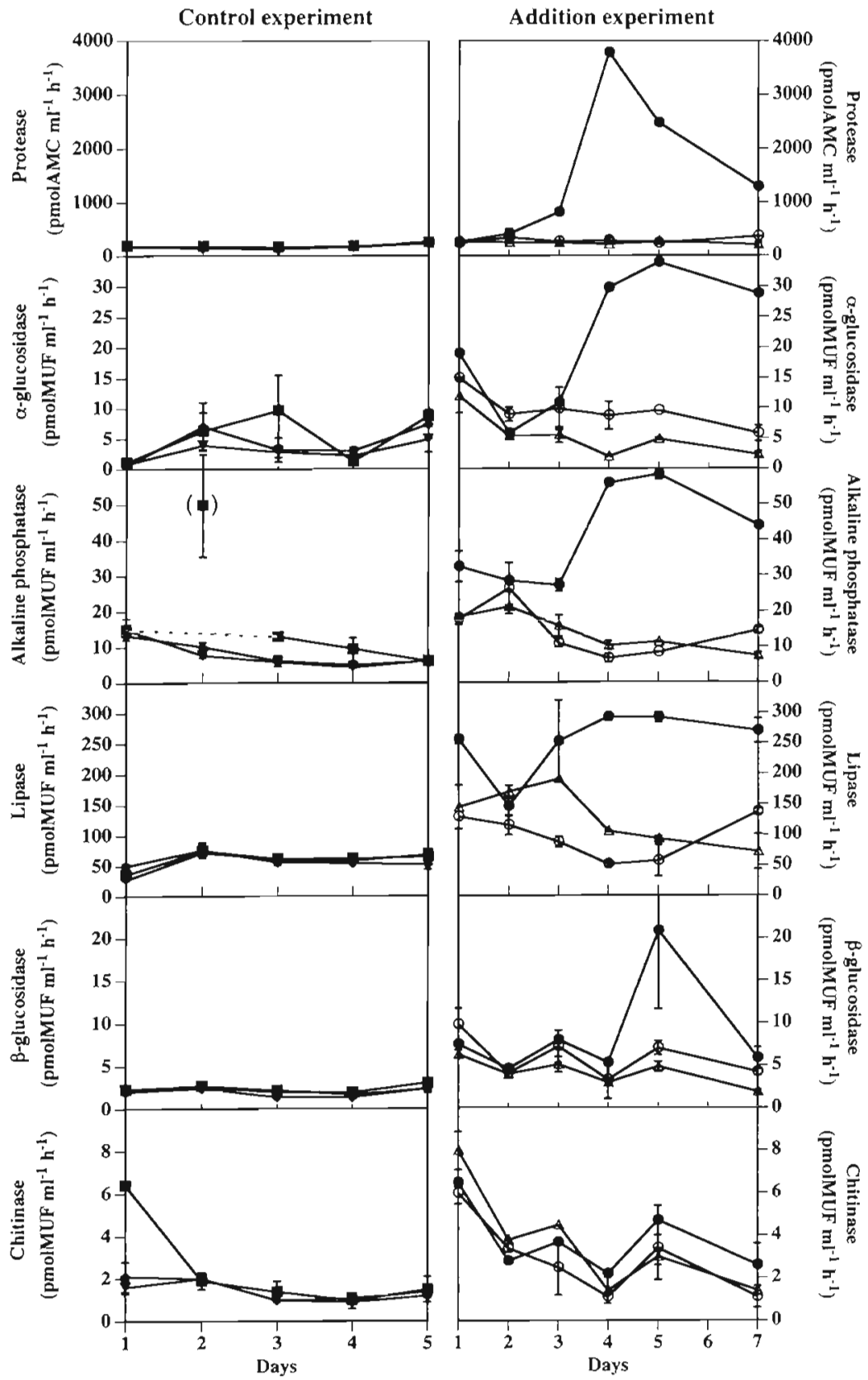

Fig. 4. Activities of the 6 determined enzymes in the three mesocosms during the control and the addition experiment. The data for mesocosm 1 (घ), $2(\bullet)$, $3(\boldsymbol{\nabla})$ in the control experiment are shown in the left panel. The data for the protein $(\bullet)$, starch $(O)$, and control mesocosms $(\Delta)$ during the addition experiment are shown in the right panel. Error bars indicate standard deviations ( $n=3$ ). When not visible error bars fall within symbols

cosm was assumed to be a sufficient control for the 2 enriched mesocosms. As in the control experiment, parallel sampling at Scripps Pier was done for comparison. The bacterial community in the protein mesocosm displayed a dynamic response to the increased substrate levels, with values of bacterial numbers, bacterial production and enzymatic activity (except pro- tease) staying within a factor 10 of the values in the control mesocosm and in situ.

\section{Bacterial numbers and production}

In the protein enriched mesocosm the number of NUCC and CTC increased significantly from Day 1 to Day 4 (Fig. 5). During this period the net accumulation of potentially viable cells, as detected by these 2 techniques, showed good agreement (approximately $3.0 \times 10^{5}$ cells $\mathrm{ml}^{-1}$, see Table 2). In the starch and control mesocosms the number of NUCC and CTC increased only slightly until Day 5 , as did the numbers at the pier (Fig. 5). The CFU in the protein mesocosm increased from 0.015 to $1.82 \times 10^{5} \mathrm{CFU}$ $\mathrm{ml}^{-1}$ from Day 1 to Day 4, whereas the CFU in the other 2 mesocosms remained in the range from 0.015 to $0.036 \times 10^{5}$ $\mathrm{CFU} \mathrm{ml}^{-1}$. The number of nucleoidcontaining cells in the protein mesocosm decreased rapidly from Day 4 to Day 5 , concomitant with an increase in heterotrophic nanoflagellates.

The increase in bacterial numbers in the protein enriched mesocosm was accompanied by an increase in bacterial production (as TTI and TLI) from Day 1 to Day 4, and the production remained higher than in the control until Day 7 (Fig. 2). The elevated bacterial production could largely be accounted for by the protein addition. Bacterial production also increased in the starch and control mesocosms, but in these mesocosms production rates returned to initial levels after Day 3.

The community turnover rates reached higher maxima in the mesocosms during the addition experiment compared to the control experiment (Table 1), although the initial and final rates (the minimum values) were similar. Still, the turnover in the mesocosms was similar to the in situ turnover values (Table 3). In the protein mesocosm the specific turnover rates calculated from the TTI and the number of NUCC and CTC (Day 2 to 4) was about 6 -fold higher compared to the rates calculated from the numerical net increase in the number of NUCC and CTC. This suggests that substantial grazing of bacteria took place. 


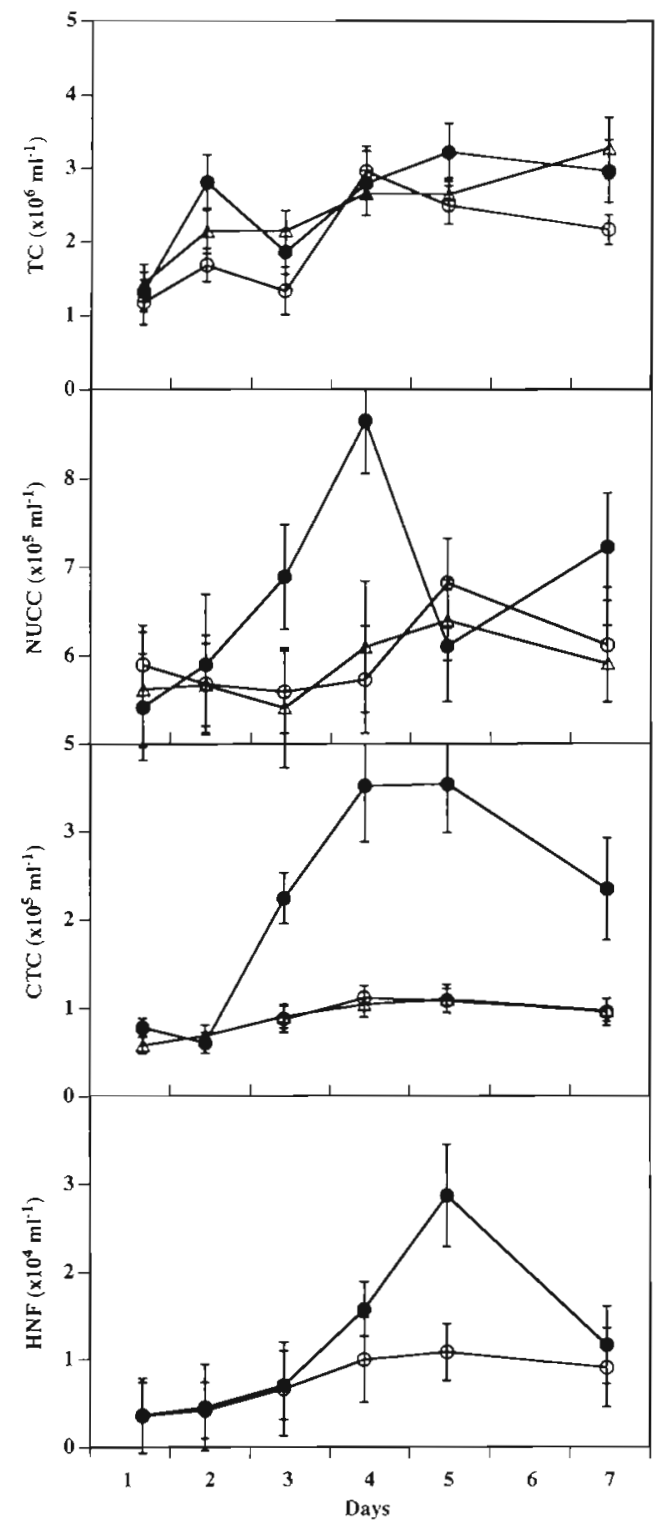

Fig. 5. Dynamics of bacterial (TC, NUCC, and CTC) and flagellate (HNF) numbers in the protein mesocosm (-) compared to the starch $(0)$ and control $(\Delta)$ mesocosms during the addition experiment. Error bars indicate standard deviations $(\mathrm{n}=30)$

Flagellate and cyanobacteria numbers

Following the initial increases in bacterial production and bacterial numbers the flagellate numbers also increased. In the protein amended mesocosm a pronounced maximum in flagellate numbers was observed $24 \mathrm{~h}$ after the peak in NUCC (Fig. 5). In this mesocosm the number of heterotrophic flagellates increased exponentially at a rate of $0.70 \mathrm{~d}^{-1}$ (regression analysis, $\mathrm{p}<0.005, \mathrm{R}^{2}=0.99$ ) reaching numbers that were 7 -fold higher than on Day 1 . In the starch and control mesocosms, flagellate numbers increased slowly, doubling over the first $5 \mathrm{~d}$.

In addition to heterotrophic bacteria the flagellates could also have consumed unicellular cyanobacteria. The cyanobacteria in the 3 mesocosms increased 1.5to 4 -fold from Day 1 to Day 3 reaching a maximum of $1.1 \times 10^{5}$ cells $\mathrm{ml}^{-1}$ in the starch mesocosm, indicating favourable conditions for growth (despite fairly low light levels). After Day 3 the number of cyanobacteria declined in both the mesocosms and the pier samples to levels close to $2.0 \times 10^{4}$ cells $\mathrm{ml}^{-1}$. At the end of the experiment aggregates containing cyanobacteria were found at the bottom of all 3 mesocosms.

\section{Density of specific bacteria}

In the protein enriched mesocosm the total density of the 31 different bacteria increased throughout the experiment. On Day 7 their numbers reached $6.5 \times 10^{5}$ cells $\mathrm{ml}^{-1}$, corresponding to a 6 -fold increase compared to initial values (Fig. 3). Thus, the total density of these bacteria amounted to $22 \%$ of the TC and $89 \%$ of the NUCC at the end of the experiment. As seen in Table 2 the numerical increase from Day 1 to Day 4 was similar to the increase in the number of NUCC and CTC. In the starch mesocosm and the control the total density of the 31 different bacteria roughly doubled to $2.6 \times 10^{5}$ cells $\mathrm{ml}^{-1}$ during the experiment. Thus, in these mesocosms the quantified bacteria made up $10 \%$ of the TC and $43 \%$ of the NUCC on Day 7.

The growth dynamics of the 10 most abundant bacteria in the mesocosms are illustrated in Fig. 3. Four of these were $\alpha$-Proteobacteria, 2 were $\gamma$-Proteobacteria, and 4 belonged to the Flexibacter-Cytophaga-Bacteroides phylum. In the protein amended mesocosm the increase in abundance was particularly obvious for the $\alpha$-proteobacterium Sulfitobacter pontiacus (SCB32), the isolate Antarcticum sp. (SCB44) affiliated with an uncharacterized genus among the CytophagaFlexibacter group, and 3 bacteria which were only very distantly related to other known bacteria among

Table 3. Comparison of rates of turnover $\left(\mathrm{d}^{-1}\right)$ of different fractions of the bacterial community in the mesocosms and in situ during the addition experiment. Turnover rates were calculated from bacterial production (TTI) and the number of TC, NUCC, and CTC

\begin{tabular}{|lcc|}
\hline & \multicolumn{3}{c|}{ Turnover rate, mean \pm SD (range) } \\
& Mesocosms $\left(\mathrm{d}^{-1}\right)$ & Scripps Pier $\left(\mathrm{d}^{-1}\right)$ \\
\hline TC & $0.21 \pm 0.09(0.05-0.41)$ & $0.28 \pm 0.21(0.07-0.29)$ \\
NUCC & $0.63 \pm 0.32(0.26-1.24)$ & $0.61 \pm 0.26(0.23-0.84)$ \\
CTC & $3.03 \pm 1.36(1.53-6.17)$ & $5.07 \pm 1.49(2.66-6.47)$ \\
\hline
\end{tabular}


the Cytophaga-Flexibacter group (e.g. SCB36, -37 , and -38). These 5 different bacterial species all increased from very low initial numbers to become dominant (Fig. 3). The bacterium SCB37 showed the most pronounced increase; from undetectable on Day 1 to $1.24 \pm 0.09 \times 10^{5}$ cells ml $^{-1}$ on Day 7 (Fig. 3). From Day 2 to 4 , this species grew exponentially at a rate of $1.6 \mathrm{~d}^{-1}$ (Tables $1 \& 2$ ). Other bacteria also showed significant net growth rates (up to $3.0 \mathrm{~d}^{-1}$ ), with the highest rate obtained by SCB44 (Table 2). Isolates SCB32, $-36,-38$, -44 were also present in the starch and control mesocosms, although in very low densities.

\section{Ectoenzyme activity}

The addition of BSA triggered a massive increase in protease activity (14-fold) and elevated levels of lipase, $\alpha$-glucosidase (6-fold increase from Day 2 to Day 4), and alkaline phosphatase (Fig. 4). This response in enzyme activity was similar to that recorded during the pilot enrichment test after the initial control experiment. Relating the enzymatic activity to the number of cells indicated that the increase was mainly due to an increased per cell activity. The levels of $\beta$-glucosidase and chitinase remained low throughout the experiment and were similar in the 3 mesocosms. The level of enzyme activity in the starch mesocosm was similar to that in the control, although the $\alpha$-glucosidase activity was somewhat higher. Enzyme activities in the control and starch mesocosms were within the range of activities at the pier (data not shown).

\section{DISCUSSION}

\section{Dynamics of bacterial numbers and enzymatic response}

Several recent studies have raised the question whether substrate induction or the presence of different bacterial populations constitute the main factor determining in situ enzyme activity. Karner \& Herndl (1992) showed that hydrolytic enzyme activity on marine snow particles was higher than in the ambient water. The per-cell activity of the attached bacteria was higher than the activity of the free-living cells, although the concentrations of dissolved total and monomeric carbohydrates and free amino acids were similar in the 2 compartments (Karner \& Herndl 1992). This indicated the presence of 2 different communities, a suggestion also supported by DeLong et al. (1993) showing that aggregate-associated bacteria were phylogenetically different from free-living bacteria (DeLong et al. 1993). Martinez et al. (1996) found that different marine bacterial isolates expressed different levels of hydrolytic ectoenzyme activities although grown under the same conditions (Martinez et al. 1996). They proposed that shifts in species composition could 'strongly influence the rates and patterns of polymer and particle hydrolysis in seawater'. As seen in Fig. 4, the addition of protein caused a dramatic increase in the protease activity during the initial $4 \mathrm{~d}$ of the addition experiment. Also lipase, alkaline phosphatase, and $\alpha$-glucosidase activity increased in the protein mesocosm during this period. Concomitant with the increase in enzymatic activity a significant shift in bacterial species composition was detected. Notably, the 5 bacteria species that responded most increased their fraction of the potentially viable bacterial community from 4 to $25 \%$ from Day 1 to Day 4 . During this period the total density of the identified bacteria increased by $3.5 \times 10^{5}$ cells $\mathrm{ml}^{-1}$, which approximately accounted for the net accumulation of bacteria determined as NUCC or CTC positive cells. Since the degree of accuracy in the species density protocol could be affected by cross hybridization we have made control experiments to ensure a correct treatment of the samples. In these control experiments the cross hybridization levels between the more closely related isolates in this study (e.g. SCB33, -55, -56) ranged from 3 to $16 \%$. This was in accordance with previous studies showing that as $16 \mathrm{~S}$ rRNA gene sequence similarities increases from 96 to $100 \%$, the cross hybridization levels increase from 2 to $100 \%$ (Amann et al. 1992). For further discussion on the limitations of the species density protocol see Pinhassi et al. (1997). With this background our results suggested a strong coupling between the level of enzymatic activity and the composition of the bacterial community.

\section{Release of substrate limitation}

The simultaneous increase in the number of viable/ potentially viable bacteria in the protein mesocosm as scored by 3 independent methods (NUCC, CTC, and CFU) was a striking observation. The increased cell numbers can be explained by an uncoupling from protozoan grazing due to increased substrate availability (del Giorgio et al. 1996). Previous studies in the Southern California Bight have indicated N-limited growth of both phytoplankton and bacteria (Eppley \& HolmHansen 1986, Horrigan et al. 1988). Thus, in the protein amended mesocosm a release from nutrient limitation could be achieved by the increased protease activity providing the bacteria with nitrogen in amino acids. The addition of reduced carbon through the protein was roughly the same as the amount of carbon 
added in the starch mesocosm, which did not differ from the control. However, in a separate container ammonium addition to the starch amended water resulted in elevated bacterial production (data not shown). A similar in situ uncoupling event can be observed through diel variation in bacterial production and number of NUCC, showing bursts of growth, coupled to the availability of limiting nutrients (Gasol et al 1998, Zweifel et al. unpubl.). These rapid changes are possible since marine bacteria can adjust their growth rates within 4 to $16 \mathrm{~h}$ in response to changed growth conditions (Chin-Leo \& Kirchman 1990).

\section{Growth rate of community versus single populations}

In the protein mesocosm the dominant bacteria taken together (10 species) showed a net growth rate of $0.9 \mathrm{~d}^{-1}$, although specific species had much higher growth rates (Table 1). The isolate SCB37 (undescribed taxon among the Flexibacter-Cytophaga-Bacteroides phylum), obtained a net growth rate of $1.6 \mathrm{~d}^{-1}$ (generation time of $10.3 \mathrm{~h}$ ). This was 5 times faster than the community turnover calculated from the bacterial production (TTI) and TC $\left(<0.3 \mathrm{~d}^{-1}\right)$, but close to the rates obtained when normalizing bacterial production to the number of NUCC and CTC (Table 2). To our knowledge this is the first time that growth rates of individual bacterial species have been demonstrated under in situ like conditions. Although the net growth rate of SCB37 might appear high, it is feasible judging from both the growth of bacterial isolates in culture and of seawater cultures inoculated with a mixed bacterial community (Zweifel et al. 1993, 1995). As indicated by the growth of these different bacteria it can thus be concluded that a fraction of the total counts of bacteria may have growth rates much faster than the turnover of the total bacterial community, allowing rapid changes in the composition of the bacterial community

\section{Bacterial community composition}

Interestingly, the initial species composition in the mesocosms is an account of the species composition in the coastal Southern California Bight, since the samples were processed within $3 \mathrm{~h}$ of the water being collected. Thus, on 4 December (Day 1 of the control experiment) the 31 studied bacteria accounted for $20 \%$ of the total counts and $75 \%$ of the nucleoid-containing bacteria in the Bight, and the 2 most abundant species were SCB28 (Roseobacter sp.) and SCB54 (Alcanovorax sp.). In the mesocosms the CFU not surprisingly amounted to a low fraction of the $\mathrm{TC}(\leq 2 \%)$. At the same time the bacteria originally isolated from the agar plates accounted for 20 to $89 \%$ of the nucleoid-containing bacteria (up to $22 \%$ of the total counts) when quantified by whole-genome probing towards the community DNA. Although controversial, a mentioning of the ongoing discussion on what fraction of the total counts that represent viable/potentially viable cells may be relevant in this context. Several recent studies have shown that only a part ( 4 to $76 \%$ ) of what is counted as bacteria by traditional staining methods can be detected as viable cells (del Giorgio \& Scarborough 1995, Zweifel \& Hagström 1995, Heissenberger et al. 1996, Karner \& Fuhrman 1997, Vosjan \& van Noort 1998). In this study the staining of nucleoid-containing cells has been used as a tentative measure of potentially viable cells. However, Choi et al. (1996) have shown that in addition to the NUCC there are cells not stainable by the NUCC method that appear viable $(16 \%$ of the $\mathrm{TC}$ in their natural samples). These results are corroborated by Karner \& Fuhrman (1997) who demonstrated that in 7 different samples on average $49 \%$ of the total cell counts were detectable by autoradiography while $29 \%$ were detectable as nucleoid-containing. In our studies the remaining difference between CFU and NUCC has been attributed to low plating efficiency, possibly due to virus infection (Rehnstam et al. 1993), but also other mechanisms such as nutrient stress could have the same effect on viability. Based on this reasoning it should be internally consistent to accept that bacterial species able to grow on solid media can be important members of aquatic bacterial communities. This has in fact been shown by several authors in recent studies (González \& Moran 1997. Kalmbach et al. 1997, Pinhassi et al. 1997. Tuomi et al. 1997). Pinhassi et al. (1997) have reported a moderate diversity among the bacterioplankton in a coastal ecosystem based on the finding that up to $59 \%$ of the total bacterial numbers were accounted for by $<15$ species. A similar situation was demonstrated in the mesocosms during the periods of high correspondence between the number of NUCC and the density of the quantified bacteria (beginning of the control experiment, and end of the addition experiment), when less than 10 species made up a majority of the bacterial community (Fig. 3).

\section{Properties of the different bacteria}

Several of the bacteria found in the mesocosms belonged to the $\alpha 3$-subclass of the Proteobacteria. Recently this group was shown to be a dominant part of the bacterioplankton in coastal southeastern US (González \& Moran 1997). These bacteria have a salt requirement for growth and a widespread marine oc- 
currence (also found in clone libraries from various marine environments), and have variable metabolic capacities (see González \& Moran 1997, and references therein). The isolates SCB28, $-31,-32,-34,-42$, -48 matched 3 different genera within this group, namely the Roseobacter, Sulfitobacter, and a not characterized Antarctic gas vacuolate bacterium (Shiba 1992, Gosink \& Staley 1995). The genus Roseobacter is known to contain bacterio-chlorophyll $a$, but these bacteria do not grow photo-autotrophically. However, the yield is increased when grown in the light, and when starved of organic substrates the cells can remain viable longer in the light than in the dark (Shiba 1992). Other interesting members of the bacterial community in the mesocosms were species of the genera Alteromonas and Pseudoalteromonas. These are widely distributed bacteria that are frequently isolated from marine environments (Gauthier \& Breittmayer 1992). The polymer producing Alteromonas macieodii (represented by SCB33) has attracted interest for the role of exopolysaccharides in adhesion of bacteria (Raguénès et al. 1996); and it has been proposed that the exopolymer production of bacteria can contribute to the initial steps in particle formation in the sea (Heissenberger et al. 1996). Interestingly, the dots on the hybridization membrane for this bacterium (Alteromonas macleodii) appeared patchy, suggesting that it may have originated from bacterial cells concentrated on particles (data not shown). For a different purpose than this study, isolated bacteria from selected particles in the mesocosms also matched this species. Several enzymological studies have involved Pseudoalteromonas carrageenovora (represented by SCB43) due to its capacity to degrade algal polysaccharides (AkagawaMatsushita et al. 1992). Polymer degrading abilities is a widespread property found among different marine bacterial groups (i.e. Vibrio-, Cytophaga-, and Pseudomonas-like bacteria), and represents a source of solubilization of abundant bioparticles which can ultimately hinder aggregate formation (AkagawaMatsushita et al. 1992, Smith et al. 1992, 1995).

Four species out of the 5 that responded most to the addition of protein belonged to the FlexibacterCytophaga-Bacteroides group. The isolate SCB37 that showed a high growth rate in the protein mesocosm had only $87 \%$ sequence similarity to the closest matching organism in the sequence database ('Antarcticum vesiculatum'). Also the isolates SCB36 and -38 were only distantly related to their closest relatives in the sequence data banks, which were within the genera Flexibacter and Capnocytophaga, respectively. In these cases the poor match of these bacteria to known phylogenetically and physiologically characterized bacteria-probably not even the same generamakes comparisons of little use.
In this paper we have demonstrated that a moderate input of substrate can trigger a simultaneous change in the relative abundance of specific hydrolytic ectoenzymes and a shift in the bacterial species composition. It appears likely that the species shift is the cause of the changes in ectoenzyme abundance. Still, until observations based on the activity of individual species can be made causal relationships are difficult to prove. The population dynamics in these experiments have illustrated the great growth potential of bacteria and the necessity to identify bacteria to the species level in order to investigate the specific activity of the dominant members of the bacterial community. Having said this we conclude that the great challenge for the future will be to explore the microbial food web within the theoretical framework of population ecology.

Acknowledgements. We thank 2 anonymous reviewers and Jed Fuhrman for their valuable comments, and Josep Gasol for critically reading the manuscript. This work was supported by the Swedish NFR, grant BU 04452-321 and the EU project MEDEA, grant MAS3-CT95-0016 ( $\AA . H$. .), NSF grant OCE 92-19864 (F.A.), and the J. C. Kempe foundation (J.P.).

\section{LITERATURE CITED}

Akagawa-Matsushita $M$, Matsuo $M$, Koga $Y$, Yamasato $K$ (1992) Alteromonas atlantica sp. nov and Alteromonas carrageenovora sp. nov, bacteria that decompose algal polysaccharides. Appl Environ Microbiol 42:621-627

Amann RI, Lin C, Key R, Montgomery L, Stahl DA (1992) Diversity among Fibrobacter isolates: towards a phylogenetic classification. Syst Appl Microbiol 15:23-31

Chin-Leo G, Kirchman DL (1990) Unbalanced growth in natural assemblages of marine bacterioplankton. Mar Ecol Prog Ser 63:1-8

Choi JW, Sherr EB, Sherr BF (1996) Relation between presence-absence of a visible nucleoid and metabolic activity in bacterioplankton cells. Limnol Oceanogr 41:1161-1168

Chróst RJ (1989) Characterization and significance of betaglucosidase activity in lake water. Limnol Oceanogr 34 : $660-672$

del Giorgio PA, Scarborough G (1995) Increase in the proportion of metabolically active bacteria along gradients of enrichment in freshwater and marine plankton: implications on estimates of bacterial growth and production rates. J Plankton Res 17:1905-1924

del Giorgio PA, Gasol JM, Vaqué D, Mura P, Agustí S, Duarte CM (1996) Bacterioplankton community structure: protists control net production and the proportion of active bacteria in a coastal community. Limnol Oceanogr 41. $1169-1179$

DeLong EF, Franks DG, Alldredge AL (1993) Phylogenetic diversity of aggregate-attached vs. free-living marine bacterial assemblages. Limnol Oceanogr 38:924-934

Eppley RW, Holm-Hansen O (1986) Primary production in the Southern California Bight. In: Eppley RW (eds) Plankton dynamics of the Southern California Bight. Springer-Verlag. New York, p 198-199

Ferris MJ, Muyzer G, Ward DM (1996) Denaturing gradient gel electrophoresis profiles of $16 \mathrm{~S}$ rRNA-defined populations inhabiting a hot spring microbial mat community. 
A.ppl Environ Microbiol 62:340-346

Fuhrman JA, Azam F (1982) Thymidine incorporation as a measure of heterotrophic bacterioplankton production in marine surface waters: evaluation and field results. Mar Biol 66:109-120

Fuhrman JA, Lee SH, Masuchi Y, Davis AA, Wilcox RM (1994) Characterization of marine procaryotic communities via DNA and RNA. Microb Ecol 28:133-145

Fukami K, Simidu U, Taga N (1985) Microbial decomposition of phyto- and zooplankton in seawater. 1I. Changes in the bacterial community. Mar Ecol Prog Ser 21:7-13

Gasol JM, Doval MD, Pinhassi J, Calderón-Paz JI, GuixaBoixareu N, Vaqué D, Pedrós-Alió C (1998) Diel variations in bacterial heterotrophic activity and growth in the northwestern Mediterranean Sea. Mar Ecol Prog Ser 164: 107-124

Gauthier MJ, Breittmayer VA (1992) The genera Alteromonas and Marinomonas. In: Balows A, Trüper HG, Dworkin M, Harder W, Schleifer KH (eds) The Prokaryotes. SpringerVerlag, New York, p 3046-3070

Giovannoni SJ (1991) The polymerase chain reaction. In: Stackebrandt E, Goodfellow $M$ (eds) Sequencing and hybridization techniques in bacterial systematics. John Wiley \& Sons, Inc, New York, p 177-201

Giovannoni SJ, Rappé MS, Vergin KL, Adair NL. (1996) 16S rRNA genes reveal stratified open ocean bacterioplankton populations related to the green non-sulfur bacteria. Proc Natl Acad Sci USA 93:7979-7984

González JM, Moran MA (1997) Numerical dominance of a group of marine bacteria in the alpha-subclass of the class Proteobacteria in coastal seawater. Appl Environ Microbiol 63:4237-4242

Gosink JJ, Staley JT (1995) Biodiversity of gas vacuolate bacteria from Antarctic sea ice and water. Appl Environ Microbiol 61:3486-3489

Heissenberger A, Leppard GG, Herndl GJ (1996) Relationship between the intracellular integrity and the morphology of the capsular envelope in attached and free-living marine bacteria. Appl Environ Microbiol 62:4521-4528

Hoppe HG (1983) Significance of exoenzymatic activities in the ecology of brackish water: measurements by means of methylumbelliferyl-substrates. Mar Ecol Prog Ser 11: $299-308$

Hoppe HG, Kim SJ, Gocke K (1988) Microbial decomposition in aquatic environments: combined process of extracellular enzyme activity and substrate uptake. Appl Environ Microbiol 54:784-790

Horrigan SG, Hagström $\AA$, Koike I, Azam F (1988) Inorganic nitrogen utilization by assemblages of marine bacteria in seawater culture. Mar Ecol Prog Ser 50:147-150

Kalmbach S, Manz W, Szewzyk U (1997) Isolation of new bacterial species from drinking water biofilms and proof of their in situ dominance with highly specific $16 \mathrm{~S}$ rRNA probes. Appl Environ Microbiol 63:4164-4170

Karner M, Fuhrman JA (1997) Determination of active marine bacterioplankton: a comparison of universal 16Sr RNA. probes, autoradiography, and nucleoid staining. Appl Environ Microbiol 63:1208-1213

Karner M, Herndl GJ (1992) Extracellular enzymatic activity and secondary production in free-living and marinesnow-associated bacteria. Mar Biol 113:341-347

Kirchman DL, Knees E, Hodson R (1985) Leucine incorporation and its potential as a measure of protein synthesis by bacteria in natural aquatic systems. Appl Environ Microbiol 49:599-607

Lane DL, Pace B, Olsen GJ, Stahl DA, Sorgin ML, Pace NR
(1985) Rapid determination of 16S rRNA sequences for phylogenetic analysis. Proc Natl Acad Sci USA 82: $6955-6959$

Lee S, Fuhrman JA (1991) Spatial and temporal variation of natural bacterioplankton assemblages studied by total genomic DNA cross-hybridization. Limnol Oceanogr 36: $1277-1287$

Long RA, Azam F (1996) Abundant protein-containing particles in the sea. Aquat Microb Ecol 10:213-221

Martinez J, Smith DC, Steward GF, Azam F (1996) Variability in ectohydrolytic enzyme activities of pelagic marine bacteria and its significance for substrate processing in the sea. Aquat Microb Ecol 10:223-230

Moran MA, Rutherford LT, Hodson RE (1995) Evidence for indigenous Streptomyces populations in a marine environment determined with a 16S rRNA probe. Appl Environ Microbiol 61:3695-3700

Pinhassi J, Zweifel UL, Hagström $\AA$ (1997) Dominant marine bacterioplankton species found among colony-forming bacteria. A.ppl Environ Microbiol 63:3359-3366

Porter KG, Feig YS (1980) The use of DAPI for identifying and counting aquatic microflora. Limnol Oceanogr 25 : $943-948$

Raguénès $G$, Pignet $P$, Gauthier $G$, Peres $A$, Christen $R$, Rougeaux H, Barbier G, Guezennec J (1996) Description of a new polymer-secreting bacterium from a deep-sea hydrothermal vent, Alteromonas macleodii subsp. fijiensis, and preliminary characterization of the polymer. Appl Environ Microbiol 62:67-73

Rath J, Schiller C, Herndl GJ (1993) Ectoenzymatic activity and bacterial dynamics along a trophic gradient in the Caribbean Sea. Mar Ecol Prog Ser 102:89-96

Rehnstam AS, Bäckman S, Smith DC, Azam F, Hagström $\AA$ (1993) Blooms of sequence-specific culturable bacteria in the sea. FEMS Microbiol Ecol 102:161-166

Rodriguez GG, Phipps D, Ishiguro K, Ridgway HF (1992) Use of a fluorescent redox probe for direct visualization of actively respiring bacteria. Appl Environ Microbiol 58: $1801-1808$

Shiba T (1992) The genus Roseobacter. In: Balows A, Trüper HG, Dworkin M, Harder W, Schleifer KH (eds) The Prokaryotes. Springer-Verlag, New York, p 2156-2159

Simon M, Azam F (1989) Protein content and protein synthesis rates of planktonic marine bacteria. Mar Ecol Prog Ser 51:201-213

Smith DC, Azam F (1992) A simple, economical method for measuring bacterial protein synthesis rates in seawater using 3H-leucine. Mar Microb Food Webs 6:107-114

Smith DC, Simon M, Alldredge AL, Azam F (1992) Intense hydrolytic enzyme activity on marine aggregates and implications for rapid particle dissolution. Nature 359: $139-142$

Smith DC, Steward GF, Long RA, Azam F (1995) Bacterial mediation of carbon fluxes during a diatom bloom in a mesocosm. Deep Sea Res 42:75-97

Suzuki MT, Rappé MS, Haimberger ZW, Winfield H, Adair N, Ströbel J, Giovannoni SJ (1997) Bacterial diversity among small-subunit rRNA gene clones and cellular isolates from the same seawater sample. Appl Environ Microbiol 63: $983-989$

Tuomi P, Torsvik T, Heldal M, Bratbak G (1997) Bacterial population dynamics in a meromictic lake. Appl Environ Microbiol 63:2181-2188

Vosjan JH, van Noort GJ (1998) Enumerating nucleoid-visible marine bacterioplankton: bacterial abundance determined after storage of formalin fixed samples agrees with 
isopropanol rinsing method. Aquat Microb Ecol 14:149-154

Williams PM (1986) Chemistry of the dissolved and particulate phases in the water column. In: Eppley RW (eds) Plankton dynamics of the Southern California Bight Springer-Verlag, New York, p 59-60

ZoBell C (1946) Marine microbiology. Monograph on hydrobacteriology. Cronica Botanica Co, Waltham

Zweifel UL, Hagström $\AA$ (1995) Total counts of marine bacte-

Editorial responsibility: Tom Fenchel,

Helsingør, Denmark ria include a large fraction of non-nucleoid-containing 'ghosts'. Appl Environ Microbiol 61:2180-2185

Zweifel UL, Norrman B, Hagstrom § (1993) Consumption of dissolved organic carbon by marine bacteria and demand for inorganic nutrients. Mar Ecol Prog Ser 101:23-32

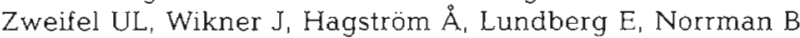
(1995) Dynamics of dissolved organic carbon in a coastal ecosystem. Limnol Oceanogr 40:299-305

Submitted: March 19, 1998; Accepted: July 20, 1998 Proofs received from author(s): February 15, 1999 